\title{
Right of the detainee to have contact with a lawyer or solicitor and to direct consultation with them as an element of the Right of Defence
}

\author{
JUSTYNA ŻYLIŃSKA \\ ORCID: 0000-0002-1199-6275 \\ Helena Chodkowska University of Technology and Economics in Warsaw
}

\section{Detainee's Right of Defence — introductory issues}

In legal doctrine, it is assumed that the right of defence embraces all and any activities undertaken in the detainee's interest — both by himself/herself as well as by other individuals who intend to counter the charge or limit the liability, as well as to reduce or eliminate any procedural nuisance. ${ }^{1}$ At the same time, a formal right of defence is distinguished manifesting itself as the right to assistance of counsel and the right of defence in the material sense construed as the right to oppose the prosecution's thesis. ${ }^{2}$

1 R. Koper, K. Marszał (ed.), J. Zagrodnik (ed.), K. Zgryzek, Proces karny (Criminal Proceedings), Warszawa 2017, p. 138.

2 See: Proces karny (Criminal Proceedings), ed. J. Skorupka, Warszawa 2017, p. 206; Kodeks postepowania karnego (Criminal Proceedings Code), Vol. 1, eds. R.A. Stefański, S. Zabłocki, Warszawa 2017, p. 120; S. Śliwiński, Polski proces karny przed sadem powszechnym. Zasady ogólne (Polish Criminal Proceedings Before the General Court), Warszawa 1959, p. 190; S. Waltoś, P. Hofmański, Proces karny. Zarys systemu (Criminal Proceedings. An Outline of the System), Warszawa 2016, p. 306. 
The right constitutes one of the fundamental human rights, proclaimed in the acts of international law, particularly in the provisions of Art. 14 section 3 sub-section d of the International Covenant on Civil and Political Rights presented for signing in New York on 19th December, $1966^{3}$ and Art. 6 section 3 subsection c of the Convention for the Protection of Human Rights and Fundamental Freedoms drafted in Rome on 4th November, $1950^{4}$ whereby it became part of the catalogue of procedural rights, i.e. the so-called minimum standard of the right to a fair criminal trial which in addition to the right of defence also includes guarantees without which the real exercising of the right of defence would not be possible. ${ }^{5}$ In light of Art. 14 section 3 of the International Covenant on Civil and Political Rights, each person accused of a crime has the right under the principle of full equality to at least the following guarantees:

Immediate provision of detailed information on the nature and cause of accusation in comprehensive language;

Adequate time and possibilities of preparing a defence and consultations with the attorney of the defendant's choice;

The trial held without unjustified delay;

Participation in the hearing, personal defence or through an attorney of the defendant's choice; where the defendant does not have an attorney, the right to information of the above-mentioned law and to have an attorney appointed in each case where it is required for the sake of justice without incurring costs of such legal defence where the defendant does not have sufficient financial resources;

Hearing or having prosecution and defence witnesses heard under the same terms and conditions;

Use of the free help of an interpreter where the defendant does not understand or speak the language of the court proceedings;

The right not to be forced to testify against oneself or to plead guilty.

3 International Covenant on Civil and Political Rights, presented for signing in New York on 19th December, 1966, Journal of Laws of 1977, No. 38, item 167.

4 Convention for the Protection of Human Rights and Fundamental Freedoms, drafted in Rome on 4th November, 1950, Journal of Laws of 1993 No. 61, item 284.

5 See: P. Hofmański (ed.), E. Sadzik, K. Zgryzek, Kodeks postępowania karnego. Komentarz do artykułów 1-296 (Criminal Proceedings Code. A Commentary on Articles 1-296), Vol. 1, Warszawa 2011, pp. 74-75. 
The above-mentioned guarantees also derive from the regulations laid down in Art. 6 of the Convention for the Protection of Human Rights and Fundamental Freedoms. ${ }^{6}$

At the same time the right of defence constitutes a constitutional principle. The Constitution of the Republic of Poland ${ }^{7}$ - in Art. 42 section 2, introduces a principle under which any person against whom a criminal procedure is carried out is entitled to a defence at all procedural stages. The defendant may in particular choose an attorney under the rules laid down in the Act and use a public defender. It has to be noted that the above-mentioned regulation does not impose any restrictions on the use of the right of defence nor does it make its exercising dependent upon, for example, the issue of the decision to present charges where the data sufficiently justify the suspicion that a particular has indeed committed a particular act. The right of defence is therefore applicable to any person against whom criminal action has been taken, i.e. defendant, suspect or a suspected person. ${ }^{8}$

Such a broad definition of the right of defence is approved by the Constitutional Tribunal, which acknowledges this right not only as a funda-

6 In light of Art. 6 section 3 of the Convention for the Protection of Human Rights and Fundamental Freedoms each person accused of committing an act subject to penalty has at least the right to the following:

Immediate provision of detailed information on the nature and cause of accusation in comprehensive language,

Adequate time and possibilities of preparing a defence,

A personal defence or through an attorney of defendant's choice, and to have a public attorney appointed where it is required for the sake of justice,

Hearing or having prosecution and defence witnesses heard under the same terms and conditions,

Use the free help of an interpreter where the defendant does not understand or speak the language of the court proceedings.

7 Constitution of the Republic of Poland of 2nd April, 1997 adopted by the National Assembly on 2nd April, 1997 was adopted by the Nation via constitutional referendum on 25th May, 1997 signed by the President of the Republic of Poland on 16th of July, 1997, Journal of Laws No. 78, item 483.

8 Kodeks postępowania karnego. Komentarz (Criminal Proceedings Code. A Commentary), ed. J. Skorupka, Warszawa 2018, Legalis, commentary on Art. 6 of the Criminal Proceedings Code. Also, see: M. Kolendowska-Matejczuk, P. Tarwacki, "Istota prawa do pomocy prawnej dla osoby zatrzymanej" ("The Nature of the Suspect's Right of Defence"), Palestra 2013, No. 7-8, p. 48. 
mental principle of the criminal procedure but also as a principal standard of a democratic and legal state. This right is vested in everybody from the commencement of legal action until passing of a valid sentence and also covers the executive stage. ${ }^{9}$ The view that the analysed right can be exercised from the beginning of the criminal action was also formulated by the Supreme Court in the sentence of 9th February, 2004 whereby it emphasised that the "Act on Legal Proceedings, in Chapter 27 grants the detainee a number of rights falling within the notion of the right of defence, typical of the right's nature, and exercised in the situation of a justified suspicion of the detaining authority that the detainee has committed a crime. So it is not the formal presentation of charges but the first action of judicial authorities aimed at prosecuting an individual makes him/her the subject of the right of defence". 10

The right of defence is also guaranteed from a procedural perspective. Although Art. 6 of the Criminal Procedure Code ${ }^{11}$ governing it is close to the constitutionally guaranteed right of defence, it is less precise. It is limited to a general statement that the "defendant has the right of defence" while Art. 42 section 2 of the Constitution of the Republic of Poland - as mentioned above - admits the use of the right of defence at all procedural stages. ${ }^{12}$ As the Constitution of the Republic of Poland admits direct application of its provisions, unless otherwise stipulated therein (Art. 8 section 2 of the Constitution of the Republic of Poland) and in view of the lack of

9 See: Sentence of the Constitutional Tribunal of 17th February, 2004, SK 39/02, OTK-A 2004, No. 2, item 7.

10 Sentence of the Supreme Court of the 9th February, 2004, V KK 194/03, Prosecution And the Law 2004, No. 7-8, item 11. Also, see: resolutions of the Supreme Court of: 26th April, 2007, I KZP 4/07, OSNKW 2007, No. 6, item 45 and of 20th September, 2007, I KZP 26/07, OSNKW 2007, No. 10, item 71; also, see: A.M. Tęcza-Paciorek, "Pojęcie osoby podejrzanej i jej uprawnienia" ("Definition and Rights of a Suspect"), Prosecution and the Law 2011, No. 11, pp. 56-57; and B. Nita, "Dostęp osoby zatrzymanej do pomocy obrońcy. Uwagi w związku z wyrokiem Europejskiego Trybunału Praw Człowieka z 10 marca 2009 r. w sprawie Płonka przeciwko Polsce” ("Detainees Access to Attorney. Comments in Connection with the Sentence of the European Court of Human Rights of 10th March, 2009 in the Case Płonka vs. Poland”), Palestra 2011, No. 11-12, p. 43.

11 Act of 6th June, 1997 - Criminal Proceedings Code, i.e. Journal of Laws of 2018, item 1907 as amended (abbrev. CPC).

12 Kodeks postępowania karnego. Komentarz (Criminal Proceedings Code. A Commentary), ed. A. Sakowicz, Warszawa 2016, Legalis commentary on Art. 6 CPC. 
regulations governing other applications of Art. 42 section 2, this regulation is applied directly; Art. 6 of the Criminal Proceedings Code should not be interpreted in a narrower context. ${ }^{13}$ In consequence, based on the regulations of the criminal and procedural act, there should be no doubt that a detainee is entitled to exercise the right of defence. At this point it is not possible to argue with the comments of the Supreme Bar Council presented in the opinion of 22nd February, 2012 "on practical application of Art. $245 \S 1$ of the Criminal Proceedings Code from the perspective of guarantee of the constitutional rights and freedoms of an individual and in particular the right of defence", prepared upon the request of the Constitutional Tribuna $1^{14}$ or the opinion of the Ombudsman as expressed in the letter of 25th January, 2017 to the Minister of Justice, Attorney General ${ }^{15}$ that the situation of the detainee is difficult. The uncertainty as to the nature of the hearing and possible content of the accusation of committing a criminal act which in the majority of cases is presented to the detainee is accompanied by an enormous psychological pressure linked with the situation and stress. Furthermore, such an individual does not have sufficient knowledge to protect his/her own interests and rights which may lead to a situation where decisions taken without legal counsel or attorney will generate behaviours detrimental to his/her legally protected interests. Such an individual should therefore be ensured with a possibility of contacting an attorney, or solicitor to obtain legal advice not only with regard to his/her procedural status but also with respect to further legal consequences related to his/her case upon which such a person may exercise his/her legitimate right of defence in the manner consistent with the procedural interest. Unfortunately, situations where due to lack of formal status of a suspect, a detainee is not given the procedural guarantees granted to the person with the status of a suspect in criminal proceedings is not uncommon.

13 See: P. Hofmański (ed.), E. Sadzik, K. Zgryzek, op. cit., p. 74.

$14 \mathrm{http} / /$ www.adwokatura.pl/admin/wgrane_pliki/adwokatura-tresc-8847.pdf, pp. 3-4 (access: 14.03.2019).

15 https:/www.rpo.gov.pl/sites/default/files/Wystąpienie\%20Stanisława\%20Trociuka $\% 20$ do\%20Ministra\%20Sprawiedliwości\%20w\%20sprawie\%20prawa\%20zatrzymanego\%20do\%20pomocy\%20prawnej.pdf (access: 17.03.2019). 


\section{Detainee's Right to direct contact and direct consultation with a lawyer or solicitor}

The issues linked with the detainee's right of defence are inextricably linked with the question of the right to direct contact and consultations with the lawyer or solicitor. In light of the provisions of Art. 245 CPC $\S 1 \mathrm{CPC}$, the detainee may exercise two independent rights realised upon his/her request:

- Immediate contact with a lawyer or solicitor in a comprehensive form,

- Direct consultation with a lawyer or solicitor; in exceptional situations justified by the particular circumstances, the detaining authority may reserve its presence during consultations. ${ }^{16}$

Enabling the detainee's contact with a professional legal counsel does not take place upon the initiative of the authority but the detainee. In criminal and procedural practice, relatively few detainees use this right. It is a consequence of a lack of efficient, statutorily governed system of guaranteed contact with a lawyer or solicitor. The detainee may establish such a contact if he/she is in the possession of the data and the phone number of the lawyer or solicitor whose legal aid he/she wishes to use. However, in the event of being detained and the application of an expedited procedure, the detainee may contact the lawyer or solicitor on duty at the time and place determined by the Minister of Justice (Art. 517j $\S 2$ $\mathrm{CPC}$ ). Also, there are cases where such contact is discouraged by the police, who regard the presence of the lawyer or attorney as having an adverse effect on the specifically construed good of the proceedings. ${ }^{17}$ This is not recommended and what is more, the officers are not only required to instruct the detainee of his/her rights to contact their lawyer or solicitor but also to facilitate such contact forthwith.

As regards the interpretation of the term "forthwith", determining the period of time to enable the detainee's contact with a lawyer or solicitor, it has to be noted that the criminal and procedural act fails to define it.

16 Kodeks postępowania karnego. Komentarz (Criminal Proceedings Code. Commentary), ed. J. Skorupka.

17 http://www.adwokatura.pl/admin/wgrane_pliki/adwokatura-tresc-8847.pdf, p. 4 (access: 14.03.2019). 
In Polish, this term is used as an equivalent of "as soon as possible", i.e. without undue delay. In light of the above-presented meaning, it has to be assumed that enabling the detainee's contact with a lawyer or solicitor should take place within the shortest time possible after a request has been made in consideration of the circumstances and in particular the procedural status of the detainee and technical possibilities of establishing contact with a professional whose aid the detainee may choose to use. The Supreme Court presenting its opinion in this regard in the sentence of 13th October, 2011 also emphasised that such a contact need not be established immediately as this term has to be interpreted in consideration of the reality of a specific case, especially technical possibilities and conditions deriving from the prevailing legal regulations including those linked with the appointed of the public attorney. ${ }^{18}$

It has to be emphasised that a detainee making a request referred to in Art. $245 \S 1 \mathrm{CPC}$ may refrain from providing any information regarding the circumstances of an event until he/she makes contact with the lawyer or solicitor. Otherwise, the guarantee deriving from Art. $245 \S 1 \mathrm{CPC}$ would be pointless. ${ }^{19}$ Also, the detaining authority, until the establishment of the contact referred to above, should not undertake any procedural action with the participation of the detainee except for the non-recurring action (Art. $308 \mathrm{CPC}$ ), unless the detainee has consented to the proceedings without legal counselling. ${ }^{20}$

The Criminal and Procedural Act does not specify the form in which a detainee may exercise his/her rights to legal counsel; it only provides a general stipulation that upon request, the detainee should be provided forth with a possibility of contacting a lawyer or solicitor using the available means. Although the possibilities of contact are broad and the procedural literature admits any means of communication (e.g. telephone, fax, e-mail), in practice such forms of contact are rarely used. ${ }^{21}$ Under these

18 Sentence of the Supreme court of 13th October, 2011, III KK 64/11, OSNKW 2012, No. 1, item 9.

19 P. Hofmański (ed.), E. Sadzik, K. Zgryzek, op. cit., p. 1350.

20 J.K. Pawelec, "Zatrzymanie w ujęciu znowelizowanego Kodeksu postępowania karnego" ("Detention in Light of the Updated Criminal Proceedings Code"), PS 2014, No. 6, pp. 63-75.

21 See: A. Ludwiczak, "Forma porozumiewania się zatrzymanego z adwokatem" (“A Form of Communication Between Detainee and Lawyer”), [in:] Współczesne pro- 
circumstances it seems justifiable to make the phrase used in Art. 245 $\S 1$ CPC, i.e. "available means of contact" more precise by determining that in particular it may be a telephone call. Even more so that this form of contact is directly identified as admissible with respect to temporary detainees and convicts (see: Art. 217 c $\S 1$ item 1 of the Executive Penal Code $^{22}$ ). Lack of precise phrasing in Art. $245 \S 1$ of the Criminal Procedure Code regarding the available means of contact of the detainee with the lawyer or solicitor and what follows admissibility of a certain level of discretion on the side of the detaining authority, in practice gives rise to the fear that there may occur disproportions in the execution of the detainee's, suspect's and temporarily arrested suspect's right to contact a lawyer and most importantly regarding the efficient exercising of the right of defence.

As mentioned above, the detainee's contact with a lawyer or solicitor may take the form of a direct consultation. Regarding the interpretation of the phrase direct consultation it has to be assumed that it is an interpersonal communication between the detainee and the attorney or solicitor manifesting through the exchange of messages, questions and answers to the questions. The purpose of the consultation is not only to provide legal advice with respect to the current procedural status of the detainee and the consequences of the detention, i.e. commencement of criminal action against the detainee or possible application of preventing measures, particularly temporary arrest. During this meeting, it is necessary to explain the detainee's rights and the consequences of not exercising them, but also to preliminarily prepare a so-called line of defence if the information given to the lawyer by the detaining officer indicates that charges are likely to be brought against him. ${ }^{23}$

blemy procesu karnego i wymiaru sprawiedliwości. Księga ku czci profesora Kazimierza Marszała (Contemporary Issues of Criminal Proceedings and Justice. A Volume in the Memory of Professor Kazimierz Marszal), eds. P. Hofmański, W. Zgryzek, Katowice 2003, p. 227; L.K. Paprzycki, Komentarz aktualizowany do art. 1-424 k.p.k., (Commentary Updated on Art. 1-424 CPC), LEX 2015, Commentary on Art. 245 CPC.

22 Act of 6th June, 1997 - Executive Penal Code, i.e. Journal of Laws of 2018, item 652 as amended (abbrev. EPC).

23 See: Ł. Cora, "Zastrzeżenie obecności zatrzymującego w trakcie rozmowy zatrzymanego z adwokatem, glosa do wyroku Trybunału Konstytucyjnego z 11 grudnia 2012 r." ("Reservation of Detaining Authority's Presence During Detainee's Consultations with the Attorney; a Glossary to the Sentence of the Constitutional Tribunal of 11th 
The legislator did not determine the maximum duration of the consultations between detainee and the lawyer or solicitor, nor the number of admissible meetings. Regarding these issues, it is assumed that the boundaries of the consultations are in a way determined by their objective, i.e. to discuss the detainee's status and procedural consequences of the detention. On the other hand, the interpretation of Art. $245 \S 1$ of the Criminal Proceedings Code leads to the conclusion that the detainee has an absolute right to one direct contact with a lawyer or solicitor. Where three proxies have been appointed, it is the duty of the detaining authority to ensure a possibility of direct communication with one of them. Nevertheless, the Act does not prohibit direct contact with other proxies or subsequent, direct contact with the same proxy (attorney). ${ }^{24}$

It has to be emphasised that in light of Art. $245 \S 1$ of the Criminal Proceedings Code, in exceptional situations justified by special circumstances, the detaining authority may reserve its presence during the consultations. At this point, it has to be noted that the current regulation enforceable as of 19th November 2013, is a consequence of questioning of the constitutional nature of Art. $245 \S 1$ of the Criminal Proceedings Code by the Constitutional Tribunal which after the hearing held on 11th December 2012 regarding an Application of the Ombudsman to review the compliance of Art. $245 \S 1$ of the Criminal Proceedings Code in part containing the wording: "the detaining authority may reserve its presence" with Art. 42 section 2 in connection with Art. 31 section 3 of the Consti-

December, 2012"), K 37/11, PiP 2014, No. 5. Also, see: the Justification of the Sentence of the Constitutional Tribunal of the 11th December, 2012, K 37/11, Journal of Laws, item 1447, http://isap.sejm.gov.pl/isap.nsf/download.xsp/WDU20120001447/T/D20121447TK. pdf (access: 18.03.2019).

24 See: J. Zagrodnik, "Metodyka pracy obrońcy i pełnomocnika w sprawach karnych i karnych skarbowych" ("Methods of Work of Attorney and Proxy in Criminal and Treasury Criminal Cases"), WK 2016, LEX; P. Nowak, "Zasady porozumiewania się zatrzymanego z adwokatem oraz tymczasowo aresztowanego z obrońcą w Kodeksie postępowania karnego w aspekcie konstytucyjnym and prawnomiędzynarodowym" ("The Rules for Communication Between Detainee and the Lawyer and the Temporarily Arrested with the Attorney as Laid down in the Criminal proceedings Code From the Constitutional And International Law Perspective"), CzPKiNP 2013, No. 1, p. 83; K. Zakrzewski, "Prawo podejrzanego tymczasowo aresztowanego do kontaktu z obrońcą" ("Temporarily Arrested Suspect's Right to Consultations with the Attorney"), $\mathrm{Pa}$ lestra 2013, No. 9-10, p. 63. 
tution of the Republic of Poland, ruled that Art. $245 \S 1$ of the Criminal Proceedings Code by not pointing out to relevant premises justifying the presence of the detaining authority in the consultations between the detainee and the lawyer is in breach of Art. 42 section 2 in connection with Art. 31 section 3 of the Constitution of the Republic of Poland.$^{25}$ In consequence, the legislator adopted the solution consisting in the possibility of the detaining authority's participation in the direct consultations between the detainee and his/her lawyer or solicitor nonetheless only in "exceptional situations justified by particular circumstances". In other words, it is possible in an extraordinary case and also where there are special circumstances justifying limitation of the direct contact. The doctrine assumes that it may take place where in reality, not hypothetically, there is a possibility of chicanery or verification of the alibi of the detainee. At the same time, it is emphasised that the detaining authority's presence during the direct consultations between the detainee and the attorney or solicitor should derive solely from the interest of the proceedings and the necessity to ensure the correct course of actions undertaken in connection with the detention. ${ }^{26}$ It has to be added that the detaining authority's presence during the consultations referred to above, in the absence of the premise of "exceptional situations justified by particular circumstances", may constitute the grounds for the detainee's complaint under Art. 246 $\S 1$ of the Criminal Proceedings Code.

In light of the above, a reference has to be made to the issue of procedure-related use of the information obtained by the officer present during the consultations between the detainee and the lawyer or solicitor. It is linked with the question regarding legitimacy of a potential control and recording of the consultations referred to in Art. 245 of the Criminal Proceedings Code and the possibility of using the recording of the consultations in evidence. The doctrine formulates a view of inadmissibility of use of such recording in evidence. It constitutes a document within the

25 Sentence of the Constitutional Tribunal of 11th December, 2012, K 37/11, Journal of Laws, item 1447.

26 See: R.A. Stefański, S. Zabłocki, Kodeks postępowania karnego. Komentarz (Criminal Proceedings Code. Commentary) Vol. 2, Lex - commentary on Art. 245; Kodeks postępowania karnego. Komentarz (Criminal Proceedings Code. Commentary), Vol. 1, ed. D. Świecki, Lex/El. 2019 - commentary on Art. 245. 
meaning of Art. 226 of the Criminal Proceedings Code as the physical characteristics of the recording media is not of the essence; however the content and its use in the trial is. The above-mentioned Art. 226 of the Criminal Proceedings Code prohibits the use of documents containing, among other things, defence secrets. An exception may be the situation where the court reserves that it will supervise a potential telephone conversation between the detainee and the lawyer or solicitor in which case the premises laid down in Art. 245 have to be satisfied, i.e. the supervision has to be justified by special circumstances. ${ }^{27}$ Furthermore, it is prohibited to interview lawyers or solicitors acting under Art. $245 \S 1$ as witnesses with respect to the fact he/she became aware of while providing legal counsel (Art. 178 item 1 of the Criminal Proceedings Code).

\section{Conclusions}

Summarising, an important element in the detained suspect's exercising the right of defence is his/her contact with a lawyer or solicitor or direct consultations with them. It allows in particular to obtain legal counsel not only regarding the current trial circumstances but also with respect to further legal consequences and subsequent detainee's exercising of the right of defence in the manner consistent with the actual procedural and trial interests. The detaining authority is required to make it possible for the detainee to exercise his/her duties as referred to in Art. 245 of the Criminal Proceedings Code should they so require. Unfortunately, in criminal and procedural practice the situations where the detainee, for lack of the formal status of a suspect, is not permitted to use the procedural guarantees vested in individuals with the status of a suspect in criminal proceedings.

\section{Bibliography}

Cora Ł., "Zastrzeżenie obecności zatrzymującego w trakcie rozmowy zatrzymanego z adwokatem, glosa do wyroku Trybunału Konstytucyjnego z 11 grudnia 2012 r." ("Reservation of Detaining Authority's Presence During Detainee's Consultations

27 Kodeks postępowania karnego. Komentarz. (Criminal Proceedings Code. Commentary), Vol. 1, ed. D. Świecki, commentary on Art. 245. 
with the Attorney; a Glossary to the Sentence of the Constitutional Tribunal of 11th December, 2012"), K 37/11, PiP 2014, No. 5.

Hofmański P. (ed.), Sadzik E., Zgryzek K., Kodeks postępowania karnego. Komentarz do artykutów 1-296 (Criminal Proceedings Code. A Commentary on Articles 1-296), Vol. 1, Warszawa 2011.

Kodeks postępowania karnego (Criminal Proceedings Code), Vol. 1, eds. R.A. Stefański, S. Zabłocki, Warszawa 2017.

Kodeks postępowania karnego. Komentarz (Criminal Proceedings Code. Commentary), Vol. 1, ed. D. Świecki, Lex/El. 2019.

Kodeks postepowania karnego. Komentarz (Criminal Proceedings Code. A Commentary), ed. A. Sakowicz, Warszawa 2016.

Kodeks postępowania karnego. Komentarz (Criminal Proceedings Code. A Commentary), ed. J. Skorupka, Warszawa 2018.

Kolendowska-Matejczuk M., Tarwacki P., "Istota prawa do pomocy prawnej dla osoby zatrzymanej" ("The Nature of the Suspect's Right of Defence"), Palestra 2013, No. 7-8. Koper R., Marszał K. (ed.), Zagrodnik J. (ed.), Zgryzek K., Proces karny (Criminal Proceedings), Warszawa 2017.

Ludwiczak A., "Forma porozumiewania się zatrzymanego z adwokatem” (“A Form of Communication Between Detainee and Lawyer"), [in:] Wspótczesne problemy procesu karnego i wymiaru sprawiedliwości. Księga ku czci profesora Kazimierza Marszała (Contemporary Issues of Criminal Proceedings and Justice. A Volume in the Memory of Professor Kazimierz Marszal), eds. P. Hofmański, W. Zgryzek, Katowice 2003.

Nita B., "Dostęp osoby zatrzymanej do pomocy obrońcy. Uwagi w związku z wyrokiem Europejskiego Trybunału Praw Człowieka z 10 marca 2009 r. w sprawie Płonka przeciwko Polsce" ("Detainees Access to an Attorney. Comments in Connection with the Sentence of the European Court of Human Rights of 10th March, 2009 in the Case Płonka vs. Poland"), Palestra 2011, No. 11-12.

Nowak P., "Zasady porozumiewania się zatrzymanego z adwokatem oraz tymczasowo aresztowanego z obrońcą w Kodeksie postępowania karnego w aspekcie konstytucyjnym and prawnomiędzynarodowym" ("The Rules for Communication Between Detainee and the Lawyer and the Temporarily Arrested with the Attorney as Laid down in the Criminal proceedings Code From the Constitutional And International Law Perspective"), CzPKiNP 2013, No. 1.

Paprzycki L.K., Komentarz aktualizowany do art. 1-424 k.p.k., (Commentary Updated on Art. 1-424 CPC), LEX 2015.

Pawelec J.K., "Zatrzymanie w ujęciu znowelizowanego Kodeksu postępowania karnego" ("Detention in Light of the Updated Criminal Proceedings Code"), PS 2014, No. 6. Proces karny (Criminal Proceedings), ed. J. Skorupka, Warszawa 2017.

Śliwiński S., Polski proces karny przed sadem powszechnym. Zasady ogólne (Polish Criminal Proceedings Before the General Court), Warszawa 1959.

Waltoś S., Hofmański P., Proces karny. Zarys systemu (Criminal Proceedings. An Outline of the System), Warszawa 2016. 
Tęcza-Paciorek A.M., "Pojęcie osoby podejrzanej i jej uprawnienia” ("Definition and Rights of a Suspect"), Prosecution and the Law 2011, No. 11.

Zagrodnik J., "Metodyka pracy obrońcy i pełnomocnika w sprawach karnych i karnych skarbowych" ("Methods of Work of Attorney and Proxy in Criminal and Treasury Criminal Cases"), WK 2016, LEX.

Zakrzewski K., "Prawo podejrzanego tymczasowo aresztowanego do kontaktu z obrońcą" ("The Temporarily Arrested Suspect's Right to Consultations with an Attorney"), Palestra 2013, No. 9-10.

\section{Summary}

The subject of this study is an analysis of the detainee's right to have contact with a lawyer or solicitor and to direct consultation with them as an element of the right of defence. The right of defence is also applicable with respect to detainees. An important element in the process of its fulfilment is the real contact of the detainee with a lawyer or solicitor. In particular, it allows the detainee to obtain legal advice, not only with respect to the current procedural situation but also with respect to further legal consequences and ultimately effect the rights of defence to which the detainee is eligible in the manner consistent with his/her actual procedural interests.

The author's intention is to examine the scope and rules of application of the rights of the detainee as set out in Art. 245 of the Criminal Procedure Code and the analysis of its effect on the detainee's effective exercising of the right of defence.

Keywords: detainee's right; contact with a lawyer or solicitor; the right of defence. 